\title{
Analisis Dampak Limbah Buangan Limbah Pabrik Batik di Sungai Simbangkulon Kab. Pekalongan
}

\author{
Muhammad Zammi*, Atik Rahmawati, Ratih Rizqi Nirwana \\ Jurusan Kimia, Fakultas Sains dan Teknologi, Universitas Islam Negeri Walisongo Semarang, Indonesia \\ *Email: zammi@walisongo.ac.id
}

\begin{abstract}
Abstrak
Tujuan penelitian ini untuk mengetahui apakah sungai Simbangkulon sudah tercemar ataupun tidak berdasarkan baku mutu yang dikeluarkan/ditetapkan oleh pemerintah/lembaga yang berwenang. Penentuan stasiun pengamatan pada lokasi penelitian didasarkan pada kegiatan masyarakat di Simbangkulon sebagai pusat pembuangan limbah batik. Hasil analisa parameter fisika dan kimia (suhu, pH dan DO) pada air sungai dibandingkan dengan Kriteria Baku Mutu Air Sungai berdasarkan Surat Keputusan Menteri Negara Kependudukan dan Lingkungan Hidup Nomor: KEP-02/MENKLH/I/1988 Tentang Penetapan Baku Mutu Lingkungan dan Peraturan Pemerintah Republik Indonesia Nomor 82 Tahun 2001 Tentang Pengelolaan Kualitas Air dan Pengendalian Pencemaran Air. Berdasarkan hasil penelitian, pH air sungai Simbangkulon antara 6,70 - 6,94 dan DO antara 1,62 - 4,32 mg/L, dan suhu antara 27 - $28{ }^{\circ} \mathrm{C}$ yang berarti bahwa kuantitas limbah batik yang dibuang langsung ke sungai Simbangkulon telah mengurangi/mencemari pH dan DO air sungai Simbangkulon, sedangkan suhu belum/tidak tercemar (masih berada pada batas aman yang ditetapkan pemerintah).
\end{abstract}

Kata kunci : Limbah Batik, baku mutu air, air sungai Pekalongan

\section{Pendahuluan}

Pekalongan adalah salah satu sentra industri batik yang cukup besar. Mayoritas dari warganya bermata pencaharian sebagai pengusaha batik, mulai dari home industry hingga perusahaan besar bertaraf Internasional. Simbangkulon merupakan salah satu kelurahan di Pekalongan yang berdampingan dengan desa Wonoyoso, Kradenan dan Simbangwetan, yang juga menjadi sentra industri ini. Dampak dari industri ini menghasilkan limbah padat berupa lilin dan limbah cair dari obat pemutih maupun pewarna kain batik yang dapat menyebabkan pencemaran karena limbah tersebut dibuang langsung ke sungai-sungai sekitar.

Dalam proses produksinya, industri batik banyak menggunakan bahan-bahan kimia dan air. Bahan kimia ini biasanya mengandung padatan tersuspensi, zat organik dan inorganik yang 
mengandung logam berat (Puji, 2008). Zat-zat ini digunakan pada proses pewarnaan atau pencelupan. Sehingga pencemaran berlangsung dimana-mana dengan laju begitu cepat.

Sebelum adanya kegiatan industri yang banyak mengeluarkan bahan pencemar ke lingkungan air yang disebabkan oleh limbah domestik akibat kegiatan manusia, pencemaran fecal (tinja, feses manusia) terhadap sumber air minum sering menyebabkan penyakit-penyakit dengan perantara air (waterborne deseases) yang telah membinasakan penduduk di sejumlah kota. Banyak persediaan air perkotaan masih mengandung bakteri-bakteri patogen yang dengan konsentrasi tinggi, terutama di pemukiman penduduk yang sangat padat dan kumuh serta pemukiman yang dekat dengan bantaran sungai (Rukaesih, 2004).

Perairan adalah tempat terakhir dari semua pembuangan limbah baik limbah yang berasal dari rumah tangga maupun industri dan beberapa logam berat dalam konsentrasi yang tinggi. Sehingga limbah menjadi konsekuensi logis dari setiap pendirian suatu industri walaupun tidak semua industri menghasilkan limbah. Bila limbah yang mengandung senyawa kimia tertentu dengan berbagai bahan berbahaya dan beracun tertentu dilepas ke lingkungan maka akan mengakibatkan pencemaran, baik di sungai, tanah maupun udara. Parameter pencemaran dapat berupa parameter fisika dan kimia. Parameter suhu di dalam air dapat menjadi faktor penentu atau pengendali kehidupan flora dan fauna akuatis, yaitu jenis, jumlah dan keberadaan flora dan fauna akuatis sering kali berubah dengan adanya perubahan suhu air, terutama oleh adanya kenaikan suhu di dalam air (Chay, 2004). Selain suhu parameter lain yang penting adalah $\mathrm{pH}$ air, Mackereth et. al. dalam Effendi (2003) berpendapat $\mathrm{pH}$ mempengaruhi toksisitas suatu senyawa kimia. Senyawa amonium yang dapat terionisasi banyak ditemukan pada perairan yang memiliki pH rendah. Parameter lain DO air, Konsentrasi oksigen (DO) yang terlalu rendah akan mengakibatkan ikan-ikan dan binatang air lainnya yang membutuhkan oksigen akan mati. Sebaliknya konsentrasi oksigen terlalu tinggi juga mengakibatkan proses pengkaratan semakin cepat karena oksigen akan mengikat hidrogen yang melapisi permukaan logam (Fardiaz, 1992). Kenaikan suhu di dalam perairan menyebabkan penurunan kadar oksigen terlarut dalam air (DO). DO yang terlalu rendah, dapat menimbulkan bau yang tidak sedap akibat terjadinya degradasi atau penguraian bahan-bahan organik ataupun anorganik di dalam air (Unus, 1996).

Selain itu, ikan sebagai biota air dapat dijadikan sebagai salah satu indikator tingkat pencemaran yang terjadi di dalam perairan (Supriyanto, 2007). Dari pengamatan selama ini, hampir tidak ada spesies ikan yang hidup di perairan sungai Simbangkulon. Selain itu Lin (2011) dalam penelitiannya menyatakan bahwa dari empat stasiun pengamatan yang diteliti, pada stasiun III tidak ditemukan makrozoobentos, yaitu nilai indeks keanekaragaman, indeks keseragaman, maupun indeks dominasinya (0). Hal ini disebabkan karena lokasi stasiun III merupakan pusat pertemuan diantara limbahlimbah industri batik yang dialirkan ke sungai.

Oleh karena itu, penulis tertarik melakukan penelitian dengan mengangkat judul penelitian: Analisis Dampak Limbah Buangan Limbah Pabrik Batik di Sungai Simbangkulon Kab. Pekalongan.

\section{Metode Penelitian}

\section{Alat dan Bahan}

Alat yang digunakan terdiri dari alat titrasi Winkler, botol contoh volume $500 \mathrm{~mL}$, pH meter, termometer air raksa, pipet tetes, neraca analitik, cawan petri, labu ukur $50 \mathrm{~mL}$ dan $1 \mathrm{~L}$, tabung reaksi, botol kecil, corong, gelas ukur, pipet dan tabung reaksi. Bahan yang digunakan $\mathrm{HNO}_{3}$ pekat, penyaring vakum dan tekanan, larutan MnSO4, 2 
Pereaksi Oksigen, $\mathrm{H}_{2} \mathrm{SO}_{4}$ pekat, Na-tiosulfat, amilum dan aquades.

Prosedur Kerja

Metode Pengambilan Sampel

Pengambilan sampel air sungai dilakukan di tiga stasiun, masing-masing stasiun diambil sebanyak 3 kali sampel. Jumlah sampel air sungai $500 \mathrm{~mL}$ dimasukkan ke dalam botol yang sudah disterilkan.

Pengukuran parameter fisik dan kimiawi dilakukan dengan dua cara, yaitu cara langsung dan analisa laboratorium. Pengamatan dan pengukuran langsung di lapangan (in situ) dilakukan terhadap parameter suhu dan $\mathrm{pH}$. Sedangkan pengukuran tak langsung (ek situ) dilakukan terhadap DO. Parameter fisik dan kimia, alat dan metode disajikan pada Tabel 1.

Analisis Data (Analisis Deskriptif)

Hasil analisa pada air sungai Simbangkulon untuk melihat tingkat pencemaran dibandingkan dengan Kriteria Baku Mutu Air Sungai.

\section{Hasil Penelitian dan Pembahasan}

Berdasarkan pengamatan parameter fisik dan kimia yang dilakukan di tiga stasiun pengambilan sampel didapat hasil yang berbeda. Hasil pengamatan dapat dilihat pada Tabel 2.

Tabel 1. Parameter, Alat dan Metode yang digunakan untuk Analisa Kualitas Air Sungai Simbangkulon

\begin{tabular}{|c|c|c|c|}
\hline $\begin{array}{c}\text { Param } \\
\text { eter }\end{array}$ & Satuan & $\begin{array}{l}\text { Metode/Al } \\
\text { at }\end{array}$ & Pengukuran \\
\hline $\begin{array}{l}\text { Fisik: } \\
\text { Suhu }\end{array}$ & ${ }^{0} \mathrm{C}$ & $\begin{array}{l}\text { Termomet } \\
\text { er Air } \\
\text { Raksa }\end{array}$ & In situ \\
\hline $\begin{array}{c}\text { Kimia: } \\
\text { pH } \\
\text { DO }\end{array}$ & $\begin{array}{c}- \\
\mathrm{mg} / \mathrm{L}\end{array}$ & $\begin{array}{c}\text { pH meter } \\
\text { Titrasi } \\
\text { winkler }\end{array}$ & $\begin{array}{l}\text { In situ } \\
\text { Ek situ }\end{array}$ \\
\hline
\end{tabular}

Tabel 2. Parameter Fisik dan Kimia Air Sungai.

\begin{tabular}{ccccc}
\hline No & $\begin{array}{c}\text { Paramet } \\
\text { er }\end{array}$ & $\begin{array}{c}\text { Stasiun } \\
\text { I }\end{array}$ & $\begin{array}{c}\text { Stasiun } \\
\text { II }\end{array}$ & $\begin{array}{c}\text { Stasiun } \\
\text { III }\end{array}$ \\
\hline 1 & Suhu air & $28{ }^{\circ} \mathrm{C}$ & $27{ }^{\circ} \mathrm{C}$ & $27{ }^{\circ} \mathrm{C}$ \\
\hline 2 & pH air & 6,70 & 6,94 & 6,79 \\
\hline \multirow{2}{*}{3} & \multirow{2}{*}{ DO } & $\begin{array}{l}1,62 \\
\mathrm{mg} / \mathrm{L}\end{array}$ & $\begin{array}{l}2,16 \\
\mathrm{mg} / \mathrm{L}\end{array}$ & $\begin{array}{l}4,32 \\
\mathrm{mg} / \mathrm{L}\end{array}$ \\
\hline
\end{tabular}

\section{Parameter Fisika dan Kimia}

\section{Suhu (Temperatur)}

Dalam setiap penelitian pada ekosistem air, pengukuran suhu (temperatur) air merupakan hal yang mutlak dilakukan. Hal ini disebabkan karena kelarutan berbagai jenis gas di dalam air serta semua aktifitas biologis-fisiologis di dalam ekosistem air sangat dipengaruhi oleh temperatur. Aktivitas mikroorganisme memerlukan suhu optimum yang berbeda-beda. Akan tetapi, proses dekomposisi biasanya terjadi pada kondisi udara yang hangat (Effendi, 2003).

Parameter suhu atau temperatur, selain berpengaruh terhadap kehidupan organisme juga berpengaruh terhadap parameter lainnya (fisika dan kimia). Hasil pengukuran suhu air sungai di tiga stasiun didapatkan hasil yaitu berkisar antara $27{ }^{\circ} \mathrm{C}-28{ }^{\circ} \mathrm{C}$ (Tabel 2), berarti suhu air Sungai Simbangkulon termasuk dalam kisaran normal dan sesuai untuk perkembangan organisme. Kaidah umum menyebutkan bahwa kenaikan temperatur sebesar $10{ }^{\circ} \mathrm{C}$ akan meningkatkan laju metabolisme dari organisme sebesar 2-3 kali lipat. Akibat meningkatnya laju metabolisme, akan menyebabkan konsumsi oksigen meningkat, sementara di lain pihak dengan naiknya temperatur akan menyebabkan kelarutan oksigen dalam air menjadi berkurang (Barus, 2002).

\section{Derajat Keasaman (pH)}

Nilai pH menyatakan nilai konsentrasi ion hidrogen dalam suatu larutan, didefinisikan sebagai logaritma dari resiprokal aktivitas ion hidrogen dan secara matematis dinyatakan sebagai $\mathrm{pH}=\log 1 / \mathrm{H}^{+}$, dimana $\mathrm{H}^{+}$adalah banyaknya ion hidrogen dalam mol per liter larutan. Kemampuan air untuk mengikat atau 
melepas sejumlah ion hidrogen akan menunjukkan apakah larutan tersebut bersifat asam atau basa. Peningkatan ion hidogen akan menyebabkan nilai pH turun dan disebut sebagai larutan asam. Sebaliknya apabila ion hidrogen berkurang akan menyebabkan nilai $\mathrm{pH}$ naik dan keadaan ini disebut sebagai larutan basa (Barus, 2002). Mackereth et. al. dalam Effendi (2003) berpendapat bahwa $\mathrm{pH}$ juga berkaitan erat dengan karbondioksida dan alkalinitas. Pada $\mathrm{pH}<5$, alkalinitas dapat mencapai nol. Semakin tinggi nilai $\mathrm{pH}$, semakin tinggi pula nilai alkalinitas dan semakin rendah kadar karbondioksida bebas. $\mathrm{pH}$ juga mempengaruhi toksisitas suatu senyawa kimia. Senyawa amonium yang dapat terionisasi banyak ditemukan pada perairan yang memiliki $\mathrm{pH}$ rendah.

Nilai derajat keasaman $(\mathrm{pH})$ air sungai di tiga stasiun berkisar antara 6,70 - 6,94 (Tabel 2). Hal ini menunjukkan bahwa air sungai Simbangkulon cenderung bersifat asam. Sungai Simbangkulon merupakan tempat terakhir pembuangan segala macam limbah, mulai dari limbah industri rumah tangga hingga limbah industri batik yang memberi kontribusi besar terhadap derajat keasaman $(\mathrm{pH})$ di sungai tersebut. Berdasarkan penelitian yang dilakukan Nurdalia (2006), menyatakan bahwa limbah batik yang menjadi penyumbang pencemar terbesar pada sungai-sungai di Pekalongan memiliki kisaran pH 8,61 - 9,42 (basa). Terjadinya perbedaan $\mathrm{pH}$ yang begitu besar antara limbah batik dengan air sungai ini karena adanya gas $\mathrm{CO}_{2}$ yang semakin tinggi, hal ini dapat dilihat dari kandungan $\mathrm{O}_{2}$ terlarut yang relatif rendah.

\section{Oksigen Terlarut (D0 = Dissolved Oxygen $)$}

Oksigen merupakan salah satu gas yang terlarut dalam perairan. Kadar oksigen yang terlarut di perairan alami bervariasi, tergantung pada suhu, salinitas, turbulensi air dan tekanan atmosfer. Semakin besar suhu dan ketinggian (altitude) serta semakin kecil tekanan atmosfer, kadar oksigen terlarut semakin kecil. Pada umumnya permukaan air sungai dalam keadaan normal mengandung $\mathrm{O}_{2}$ terlarut sebesar $8,2 \mathrm{mg} / \mathrm{L}$ pada suhu $26{ }^{\circ} \mathrm{C}$ (Fardiaz, 1992). $\begin{array}{lccr}\text { Berdasarkan } & \text { pengamatan, } & \text { diperoleh } \\ \text { kandungan oksigen } & \text { terlarut di } & \text { sungai } \\ \text { Simbangkulon antara } & 1,62 \mathrm{mg} / \mathrm{L} & -4,32 \mathrm{mg} / \mathrm{L}\end{array}$ (Tabel 8). Dari ketiga stasiun tampak jelas bahwa kadar oksigen sangat rendah dari baku mutu air sungai secara normal. Pada stasiun 1 kadar $\mathrm{O}_{2}$ paling rendah, yaitu $1,62 \mathrm{mg} / \mathrm{L}$, ini disebabkan karena adanya limbah usaha pencucian jinswash yang mengandung limbah organik yang dialirkan ke sungai tanpa adanya pengolahan terlebih dahulu.

Adapun pada stasiun 2 kandungan $\mathrm{O}_{2}$ yang rendah $(2,16 \mathrm{mg} / \mathrm{L})$ disebabkan karena pada stasiun ini merupakan daerah pencemaran limbah batik yang dialirkan ke sungai tanpa adanya pengolahan terlebih dahulu. Limbah organik dari limbah batik akan mengalami degradasi dan dekomposisi oleh bakteri aerob menggunakan oksigen dalam air, sehingga lama-kelamaan oksigen terlarut akan sangat berkurang. Rendahnya kadar $\mathrm{O}_{2}$ ini dapat dilihat dari hasil penelitian Millah (2011), yaitu angka COD berkisar $120 \mathrm{mg} / \mathrm{L}$ yang melebihi batas baku mutu air. Selain itu disebutkan juga bahwa pada stasiun ini hanya ditemukan satu makrozoobentos yaitu Pila polita, dengan indeks keanekaragaman (0), indeks keseragaman (0), dan indeks dominasi (0). Hal ini sesuai dengan pernyataan Riyadi (1981) yang menyebutkan hadirnya sampah maupun kotoran di dalam sungai menggoncangkan "energy flow" bagi kehidupan air, karena hilangnya persediaan oksigen yang sangat vital bagi kehidupan air, maupun kelangsungan proses dekomposisi secara aerob.

Dari ketiga stasiun, stasiun ketiga merupakan stasiun yang mengandung oksigen terlarut paling tinggi $(4,32 \mathrm{mg} / \mathrm{L})$ walaupun masih berada di bawah standar baku mutu air. Hal ini disebabkan karena stasiun 3 berada di bawah aliran stasiun 2, adanya limbah batik yang mengandung material organik sebagian besar sudah mengalami dekomposisi di stasiun 2, sehingga kadar $\mathrm{O}_{2}$ pada stasiun 3 lebih besar dari pada stasiun 2 (Tabel 2).

Kadar $\mathrm{O}_{2}$ di sungai Simbangkulon antar stasiun terjadi perbedaan, tergantung pada lokasinya. Hal ini sesuai dengan pernyataan Effendi (2003), yang menyatakan bahwa kadar 
oksigen terlarut dapat berfluktuasi secara harian (diurnal) dan musiman, tergantung pada pencampuran (mixing) dan pergerakan (turbulence) massa air, aktivitas fotosintesis, respirasi, dan limbah (effluent) yang masuk ke badan air.

\section{Kesimpulan}

Berdasarkan penelitian yang telah dilakukan, maka dapat diambil kesimpulan bahwa pada air sungai Simbangkulon ditinjau dari suhu masih berada pada taraf aman dan belum tercemar. Sedangkan ditinjau dari pH dan DO-nya air sungai Simbangkulon sudah tercemar dan melebihi baku mutu yang ditetapkan pemerintah RI.

\section{Daftar Pustaka}

Achmad, Rukaesih. 2004. Kimia Lingkungan. Yogyakarta: Andi

Alexander Barus, Ternala. 2002. Pengantar Limnologi. Medan: Universitas Sumatera Utara

Ashdak, Chay. 2004. Hidrologi dan Pengelolaan Daerah Aliran Sungai. Yogyakarta: Gadjah Mada University Press

Effendi, Hefni. 2003. Telaah Kualitas Air. Yogyakarta: Kanisius

Fardiaz, Srikandi. 1992. Polusi Air dan Udara, Yogyakarta: Kanisius

Nurdalia, Ida. 2006. Kajian Dan Analisis Peluang Penerapan Produksi Bersih Pada Usaha Kecil Batik Cap: Studi Kasus Pada Tiga Usaha Industri Kecil Batik Cap di Pekalonagn. Tesis. Semarang: Program Pascasarjana Universitas Diponegoro.

Riyadi, A. L. Slamet. 1981. Ekologi Ilmu Lingkungan (Dasar-Dasar dan Pengertiannya). Surabaya: Usaha Nasional.

Silfa Millah, Lin. 2011. Pengaruh Limbah Industri Batik terhadap Komunitas Makrozoobentos sungai Simbangkulon di Kecamatan Buaran Kabupaten Pekalongan. Skripsi. Semarang: Program Studi Pendidikan Biologi Fakultas Pendidikan Matematika dan Ilmu Pengetahuan Alam IKIP PGRI.

Subagio, Puji Yosep. 2008. Tekstil Tradisional (Pengenalan Bahan dan Teknik). Jakarta: Studio Primastoria.

Supriyanto C., et.al. 2007. Analisis Cemaran Logam Berat $\mathrm{Pb}, \mathrm{Cu}$, dan $\mathrm{Cd}$ pada Ikan Air Tawar dengan Metode Spektroskopi Nyala Serapan Atom (SSA). Prosiding, Seminar Nasional III SDM Teknologi Nuklir, 21-22 November 2007. Yogyakarta: Pusat Teknologi Akselerator dan Proses Bahan.

Suriawiria, Unus. 1996. Air Dalam Kehidupan dan Lingkungan Yang Sehat. Bandung: Penerbit Alumni. 